\title{
Performance Comparison Between a Natural and a Commercial Antioxidant on Smoked Pacu (Piaractus mesopotamicus)
}

\author{
Luzilene A. Cassol ${ }^{1}$, Edivaldo S. de Almeida Filho ${ }^{1} \&$ Anderson C. S. de Oliveira ${ }^{1}$ \\ ${ }^{1}$ Federal University of Mato Grosso, Mato Grosso, Brazil \\ Correspondence: Luzilene A. Cassol, Federal University of Mato Grosso, Cuiabá, Av. Fernando Corrêa da Costa \\ s/n, Mato Grosso, Brazil. Tel: 55-65-98115-0702. E-mail: 1z_cassol@yahoo.com.br
}

Received: August 21, 2018

Accepted: November 5, $2018 \quad$ Online Published: January 15, 2019

doi:10.5539/jas.v11n2p225

URL: https://doi.org/10.5539/jas.v11n2p225

\begin{abstract}
Fish consumption has grown in Brazil, but the lack of diversification in the offer of processed products restricts this eating habit. Moreover, the fact that industrialized products contain chemical additives threatens the image of fish as a healthy protein. Thus, the present study proposes not only to develop a product with antioxidant action, but also to apply it and compare it with a commercial antioxidant added to smoked pacu (Piaractus mesopotamicus) ribs. For this purpose, a meal was produced from the pulp of 'jatobá' (Hymenaea courbaril) fruit and its total phenolic content and antioxidant potential were tested. After its antioxidant power was proven, an experiment with 90 samples was carried out to test six storage times and five meal concentrations as a completely randomized design (CRD) with a factorial arrangement. Phase 2 was conducted with the most indicated concentration of the product, which was applied to 360 samples in a CRD with a factorial arrangement in which the factors corresponded to six storage times and two types of antioxidant (natural: jatobá meal; and commercial: butylated hydroxytoluene [BHT]) plus a control treatment. Microbiological, physicochemical, and sensory analyses were used for the evaluation. Results showed that the jatobá meal was effective as an antioxidant at the concentration of $4.5 \%$ to ensure a shelf life of 5 days under refrigerated storage, whereas BHT $(100 \mathrm{mg} / \mathrm{g})$ provided a shelf life of 10 days to the product and the treatment without antioxidant resulted in a shelf life of one day.
\end{abstract}

Keywords: native fish, oxidation, processing

\section{Introduction}

The average per capita consumption of fish in Brazil in 2011 was $11.17 \mathrm{~kg} /$ person/year- $14.5 \%$ more than the previous year (MPA, 2013) — which indicates increased fish consumption in the country. Ogawa \& Maia (1999) stressed that this increase should also be present in processed form (ready-/semi-ready-to-eat), given the little available time of today's society for their preparation. For this reason, smoked cuts of fish can provide both conditions, representing an excellent alternative for those wishing a balanced, easy, and fast eating lifestyle. Butylated hydroxytoluene (BHT) is an antioxidant largely used in Brazil in several meat products (Evangelista, 2003).

Research has shown the relevance of antioxidants of natural origin as an alternative. Natural antioxidants are substances found mainly in plant-derived foods. Among the fruits found in the Brazilian cerrado vegetation, the 'pequi', 'cumbaru', and 'jatobá' (Hymenaea courbaril) stand out for their antioxidant properties. The leaves, peel, and pulp of jatobá contain terpenic and phenolic compounds with antimicrobial action, which validates their history of use against diverse illnesses (Guarim Neto \& Morais, 2003). These compounds include phenolic acids, which have antioxidant properties.

In view of the above-stated scenario, the present study was conducted to develop a jatobá meal, determine its best concentration for use, and test it in comparison with BHT by evaluating the effectiveness of both on smoked and chilled pacu ribs. The present results may be used to support discussions in the scientific community and help industries with regard to the diversification of fish products and the use of antioxidants. 


\section{Methods}

\subsection{Phase I}

\subsubsection{Production of the Jatobá Meal}

The jatobá fruit was acquired from rural producers in the region of Poconé-MT, Brazil, from 09/26 to 10/28/2015. The fruits were transported to the Laboratory of the Federal Institute of Mato Grosso (IFMT/Cuiabá), washed in running potable water, and cleaned by immersion in $150 \mathrm{ppm}$ sodium hypochlorite for $15 \mathrm{~min}$. After the pulp was obtained, the peel and the seed were removed and it was then chopped, placed on trays, and dried in an oven at $50^{\circ} \mathrm{C}$. The drying time was determined by weighing the sample every $1 \mathrm{~h}$. The drying process was concluded when there was no difference between the last two weighings. Phenolic contents were determined following Larrauri et al. (1997), while the antioxidant activity was determined by the ABTS (2,2'-azino-bis(3-ethylbenzothiazoline-6-sulphonic acid)) capture method, in accordance with Rufino et al. (2007).

\subsubsection{Determination of the Best Concentration of Use of Jatobá Meal}

Considering the existing studies involving the use of jatobá meal as an antioxidant, we chose to use five concentrations of the product on smoked fish, namely 0 (control), 1.5, 3.0, 4.5, and 6.0\%. Ninety (90) ribs of pacu (average weight $120 \mathrm{~g}$ ) were used to test these the afore-mentioned concentrations at $0,3,6,9,12$, and 15 days. The experiment was conducted as a CRD with a factorial arrangement where the factors consisted of six storage times $(0,3,6,9,12$, and 15 days) and five meal concentrations $(0,1.5,3.0,4.5$, and $6.0 \%)$, with three replicates, in which we measured the $\mathrm{pH}$ and the peroxide index (PI). Statistical analyses were run in R Development Core Team (2015) software.

\subsection{Phase II}

\subsubsection{Microbiological Analyses of the Raw Material}

The raw material was analyzed following Silva (2010), before processing, to validate its quality. Coagulase-positive Staphylococcus and Salmonella spp. were quantified, as determined in RDC Resolution no. 12 (ANVISA, 2001). Total coliform and aerobic mesophilic heterotrophic bacteria counts are not provided for in this legislation.

\subsubsection{Processing of the Pacu Ribs}

A total of 360 pacu ribs (average weight: $120 \mathrm{~g}$ ) were processed by undergoing the smoking process using the two antioxidants in addition to control group (without antioxidants) at $0,3,6,9,12$, and 15 days. Based on the studies of Gonçalves (2011) on the smoking of meat and marine-fish products, a processing flow chart was designed for the production of smoked pacu comprising the following sequential steps: reception of raw material, brining, dripping 1, immersion in liquid smoke (smoking stage 1), dripping 2, hot drying (smoking stage 2), chilling, packing, and cold storage. In the brining stage, the raw material was immersed in brining solutions ( $\mathrm{S} 1$, S2, and S3) at a fish:brine ratio of 1:1, containing the same salt concentration in their base formulation (10\%), as follows: S1-with the commercial antioxidant BHT $\left(\operatorname{Synth}^{\circledR}\right)$ at $100 \mathrm{mg} / \mathrm{g}(10 \%)$, according to the maximum limit of addition allowed by the Ministry of Health (Brasil, 2007); S2-with an antioxidant of natural origin at the best concentration of use tested (item 2.2); and S3-no antioxidant.

After $5 \mathrm{~min}$ in the brine solutions, samples were removed for the dripping of excess fluid for another $5 \mathrm{~min}$. Next, they were immersed in liquid smoke $\left(\operatorname{Newmax}{ }^{\circledR}\right)$ for $10 \mathrm{~min}$ and left to drip again also for $10 \mathrm{~min}$ to eliminate excess fluid. The samples were then oven-dried at 65 to $70{ }^{\circ} \mathrm{C}$ for $55 \mathrm{~min}$. Subsequently, the product was placed in a refrigerator at a maximum temperature of $4{ }^{\circ} \mathrm{C}$ for $6 \mathrm{~h}$. Lastly, the product was packed under conventional atmosphere in a package composed of a Styrofoam tray lined with adherent plastic film. The product was stored under refrigeration at $4{ }^{\circ} \mathrm{C}$ for 15 days. On the day after processing, samples were removed for the sensory analysis. During storage, samples were removed every three days for the previously defined microbiological and physiochemical analyses (first removal on day 0 and the others on the subsequent days, until the 15 th day).

2.2.3 Sensory analysis of the processed product

Sensory analysis was performed after processing to determine the public acceptance and purchase intention of the developed formulations. The analysis was undertaken by 285 untrained tasters from three higher-education institutions (two public and one private), aged 19 to 50 years. Tasters received coded samples in a random order together with an assessment file with a 9-point hedonic scale that ranged from 'dislike extremely' (score 1) to 'like extremely' (score 9) that also contained questions about their frequency of fish consumption as well as their frequency of consumption of smoked products. For this assessment, a CRD was implemented where the 
treatments consisted of the two types of antioxidant. The following criteria were evaluated: taste, color, aroma, texture, and overall appearance. The questionnaire also included questions pertaining to the tasters' attitude, aiming to express their possible purchase intention, ranging from 'would certainly buy' (score 5) to 'would certainly not buy' (score 1). Lastly, their demographic profile was determined based on responses related to sex, age, and type of education institution. The statistical analysis was performed using non-parametric analysis of variance by the Friedman test, in R Development Core Team (2015) software.

\subsubsection{Microbiological and Physicochemical Analyses for Comparison Between the Antioxidants}

Microbiological analyses were performed according methodologies described by Silva (2010) and RDC Resolution no. 12 (ANVISA, 2001), comprising the following parameters: Salmonella spp, coagulase-positive Staphylococcus, and count of total and thermotolerant coliforms. In addition, total count of aerobic mesophilic heterotrophic microorganisms was performed and sulfite-reducing clostridia at $46{ }^{\circ} \mathrm{C}$ and aerobic psychrotrophic heterotrophic microorganisms and molds/yeasts were quantified. The following physicochemical and centesimal composition analyses were carried out after processing, over a defined storage period, following methodologies proposed by the Adolfo Lutz Institute (2008): PI, thiobarbituric acid (TB), $\mathrm{pH}$ (internal part of the meat), salt content, and centesimal composition (moisture, lipids, protein, and ash). The experiment was conducted as a CRD with a factorial arrangement in which the factors consisted of six storage times $(0,3,6,9,12$, and 15 days) and two types of antioxidant (natural and commercial) plus a control group (no antioxidant), with three replicates. Statistical analyses were performed in R Development Core Team (2015) software. The study was approved by the local Research Ethics Committee (approval no. 36002614.0.0000.5541).

\section{Results and Discussion}

\subsection{Phase I}

\subsubsection{Production of the Jatobá Meal}

The obtained amount of total phenols was $86.23 \pm 0.61 \mathrm{mg} / 100 \mathrm{~g}$ in the aqueous extract and $21.32 \pm 0.35 \mathrm{mg} / 100 \mathrm{~g}$ in the ethanolic extract. The detected antioxidant activity, in turn, expressed as $\mathrm{EC}_{50}$ (extract concentration in $\mu \mathrm{g} / \mathrm{mL}$ capable of inhibiting $50 \%$ of the free radical present), was $221.27 \mu \mathrm{g} / \mathrm{mL}$ in the aqueous extract and $545.49 \mu \mathrm{g} / \mathrm{mL}$ in the ethanolic extract. The data show better results for the aqueous extract, suggesting that pure water showed a better phenolic compound-extraction capacity than the ethanolic solution, indicating presence of highly polar phenolic compounds. There are no literature data about the phenolic content and the antioxidant capacity of jatobá. However, the total phenolic data obtained here, e.g. passion fruit (peel), $20 \mathrm{mg} / 100 \mathrm{~g}$ total phenols in the aqueous extract; buriti (Mauritia flexuosa) (meal), $27.7 \mathrm{mg} / 100 \mathrm{~g}$; ata (Annona squamosa) (seed), $81.7 \mathrm{mg} / 100 \mathrm{~g}$; açaí (Euterpe oleracea) (pulp), $133 \mathrm{mg} / 100 \mathrm{~g}$; mango (pulp), $544 \mathrm{mg} / 100 \mathrm{~g}$; and acerola (Malpighia emarginata) (peel+pulp), $580 \mathrm{mg} / 100 \mathrm{~g}$ (Souza et al., 2007), reveal a satisfactory quantity of total phenols in the jatobá meal produced. On this basis, it can be assumed that this product may have good antioxidant activity.

\subsubsection{Determination of the Best Concentration of Use of Jatobá Meal}

Figure 1 shows the regression models for the peroxide index (PI) (meq/1000 g) as a function of the concentration of jatobá meal within each time.

There was no difference between the concentrations at time 3 . For the other times, the best-fitting model was the quadratic type, indicating that the index declines up to a certain concentration and then rises again; this concentration is termed 'saturation concentration'.

Based on the models, we determined the saturation level for each time, as follows: Time 6 (concentration: $4.5 \%$ ), Time 9 (concentration: 4.44\%), Time 12 (concentration: 4.92\%), and Time 14 (concentration: $4.57 \%$ ). In this way, the best concentration for the lowest PI value would be between 4.44 and 4.92, depending on the storage time. 


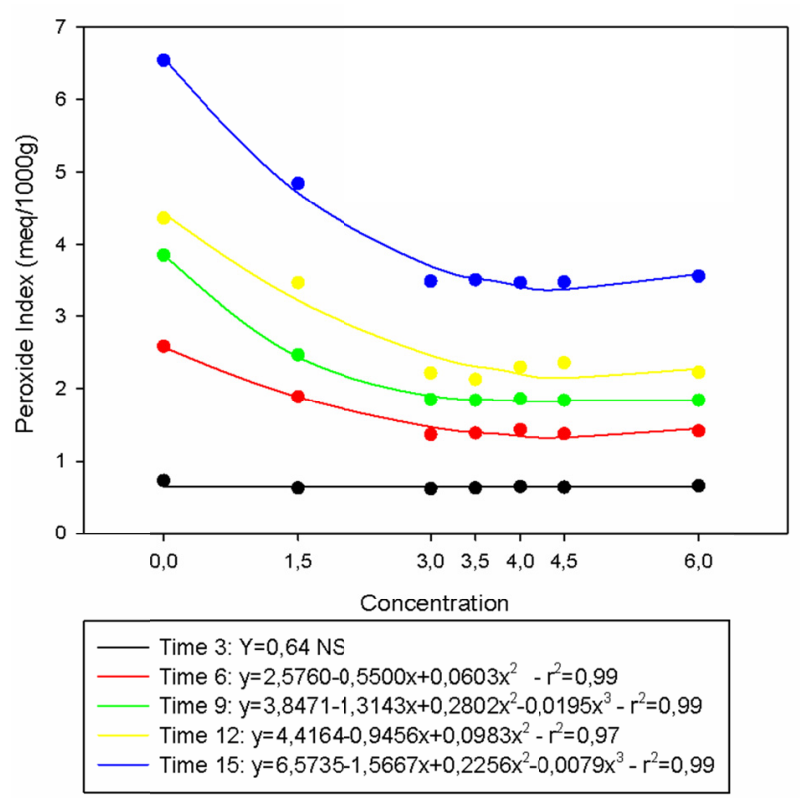

Figure 1. Regression of peroxide index as a function of the meal concentration at each storage time

\subsection{Phase II}

\subsubsection{Microbiological Analyses of the Raw Material}

The analyzed raw-material samples did not exhibit significant levels of the studied microorganisms, namely total coliforms $\left(<1.0 \times 10^{1} \mathrm{CFU} / \mathrm{g}\right)$, coagulase-positive Staphylococcus $\left(5.0 \times 10^{2} \mathrm{CFU} / \mathrm{g}\right)$, mesophilic heterotrophic bacteria $\left(1.1 \times 10^{1} \mathrm{CFU} / \mathrm{g}\right)$ and Salmonella spp. (absent/25g).

Results show good raw-material quality and suggest it was obtained in conformity with good sanitary practices. These findings were expected, since the fish were acquired from a fish plant inspected by the Ministry of Agriculture, Livestock, and Food Supply (MAPA) of Brazil, which requires it to conform to the quality parameters established by law. Analogous results were obtained by Delbem et al. (2010), who evaluated the microbiological quality of spotted sorubim (Pseudoplatystoma corruscan) fresh and stored on ice and found total coliform and mesophilic bacteria counts $\leq 1.0 \times 10^{1} \mathrm{CFU} / \mathrm{g}$ and absence of Salmonella spp.

\subsubsection{Sensory Analysis of the Processed Product}

According to the results of the Friedman test, there was no significant difference in the evaluation of the sensory variables $(\mathrm{p} \geq 0.05)$. The scores for taste, aroma, texture, and overall appearance remained between 6.8 and 7.1 for the samples with both the commercial and natural versions of antioxidant, which shows that the tasters did not distinguish the samples with different antioxidants. This observation suggests that the use of the natural antioxidant instead of its commercial counterpart is possible.

The scores assigned for taste, color, aroma, texture, and appearance were near 7.0 ('like moderately'). According to Dutcosky (2013), on a 9-point hedonic scale, these scores indicate good acceptance of the product. As for the purchase intention, scores ranged from 3 ('might buy/might not buy') to 4 ('would possibly buy'), on a 5-point scale, which is also considered by that author as a good result. Similar results for taste, color, aroma, and appearance were found by Minozzo (2002), who evaluated the acceptance of smoked tilapia (Oreochromis nilóticus) filets and obtained values between 6.0 and 7.0 for these scores, on a 9-point scale. However, that author also reported values between 2.0 and 3.0 for texture and purchase intention, differing from our findings. This fact can be explained by the difference between the studied cuts, since the fillet has less fat than the rib, and after the natural drying process caused by hot smoking, the filet is expected to show greater resistance to biting than the rib. Santos et al. (2007) conducted a sensory evaluation of smoked tilapia filet on a 9-point scale using rosemary as antioxidant and found results similar to those presented here for color (7.0), aroma (7.9), and appearance (7.2). Overall, the present results demonstrate good acceptance of the smoked fish, indicating that this technology can be better exploited as a processing alternative. Furthermore, the gap pointed by this study with respect to both fish consumption and the consumption of smoked foods is relevant, since $45 \%$ of the tasters stated they consume fish occasionally and 53\% said they consume smoked foods also occasionally. In view of 
these results, and considering the good acceptance and purchase intention of smoked fish, it can be inferred that the above-mentioned occasional consumption is likely related to the low availability of this product to consumers. The tasters' assessment was not influenced by the factors sex, age, or type of education institution.

\subsubsection{Microbiological and Physicochemical Analyses for Comparison Between the Antioxidants}

(1) Sulfite-reducing clostridia at $46{ }^{\circ} \mathrm{C}$, total coliforms, coliforms at $45{ }^{\circ} \mathrm{C}$, Salmonella spp and coagulase-positive Staphylococcus: these showed no significant values throughout the storage time ( $0 \mathrm{CFU} / \mathrm{g}$ for sulfite-reducing clostridia, $<1.0 \times 10^{1} \mathrm{CFU} / \mathrm{g}$ for total coliforms and coliforms at $45{ }^{\circ} \mathrm{C}$, absence $/ 25 \mathrm{~g}$ for Salmonella spp, and $<1.0 \times 10^{2} \mathrm{CFU} / \mathrm{g}$ for coagulase-positive Staphylococcus).

RDC Resolution no. 12 of Anvisa (ANVISA, 2001) determines the following microbiological standards for this type of product: Coliforms at $54{ }^{\circ} \mathrm{C} / \mathrm{g}$-maximum $1 \times 10^{3}$; coagulase-positive Staphylococcus - maximum $3 \times$ $10^{3}$; Salmonella spp $/ 25 \mathrm{~g}$-absent; and sulfite-reducing clostridia at $46{ }^{\circ} \mathrm{C}-$ maximum $5 \times 10^{2}$. All results obtained over the storage period meet the standards established for these microorganisms. Similar results were obtained by Ribeiro et al. (2009), who evaluated the microbiology of smoked salmon (Salmo salar) sold in Rio de Janeiro State and found a count of $<0.3 \mathrm{MPN} / \mathrm{g}$ total coliforms and coliforms at $45{ }^{\circ} \mathrm{C} / \mathrm{g}$, absence of Salmonella spp., and 0 CFU/g of coagulase-positive Staphylococcus. Golçalves and Hernández (1998) did not find sulfite-reducing clostridia at $46{ }^{\circ} \mathrm{C}$ in bluefish (Pomatomus saltatrix) smoked with liquid smoke and stored under refrigeration, which was an analogous result to the present findings.

(2) Molds and yeasts (MY): no statistical analysis was performed for this parameter, because only the group without antioxidant showed positive results for this count (9th day: $7 \times 10^{1} \mathrm{M}$ and $4 \times 10^{1} \mathrm{Y}$; 12 th day: $6 \times 10^{3}$ $\mathrm{M}$ and $5 \times 10^{3} \mathrm{Y}$; 15 th day: $9 \times 10^{3} \mathrm{M}$ and $8 \times 10^{3} \mathrm{Y}$ )

The fact that no MY were found in the groups with natural or commercial antioxidant reveals that both were effective in inhibiting their development during the storage period. By contrast, the group without antioxidants showed counts from the 9th day because of the lack of protection provided by the antioxidants. Similar values were found by Maske et al. (2011), who studied the centesimal and microbiological compositions of Rhamdia quelen subjected to the smoking process (no antioxidants) and stored under refrigeration and found $10^{3} \mathrm{CFU} / \mathrm{g}$ at the 7th day of storage.

(3) Total count of aerobic mesophilic heterotrophic microorganisms: at time 0 , only the treatment without antioxidants differed from the others (Table 1). At the subsequent times, all treatments differed from one another.

Table 1. Mean values for $\log$ CFU of mesophiles (M) and psychrotrophs (P) as a function of treatments and time

\begin{tabular}{|c|c|c|c|c|c|c|}
\hline \multirow{3}{*}{ Time (days) } & \multicolumn{6}{|c|}{ Treatment (antioxidant) } \\
\hline & \multicolumn{2}{|c|}{ Commercial } & \multicolumn{2}{|c|}{ Natural } & \multicolumn{2}{|c|}{ No antioxidant } \\
\hline & $\mathrm{M}$ & $\mathrm{P}$ & $\mathrm{M}$ & $\mathrm{P}$ & $\mathrm{M}$ & $\mathrm{P}$ \\
\hline 0 & $0.00 \mathrm{~b}$ & $0.00 \mathrm{a}$ & $0.00 \mathrm{~b}$ & $0.00 \mathrm{a}$ & $6.25 \mathrm{a}$ & $0.00 \mathrm{a}$ \\
\hline 3 & $3.18 \mathrm{c}$ & $0.00 \mathrm{~b}$ & $4.31 b$ & $0.00 \mathrm{~b}$ & $12.51 \mathrm{a}$ & $2.80 \mathrm{a}$ \\
\hline 6 & $3.33 \mathrm{c}$ & $0.00 \mathrm{~b}$ & $5.60 \mathrm{~b}$ & $3.40 \mathrm{a}$ & $18.23 \mathrm{a}$ & $3.90 \mathrm{a}$ \\
\hline 9 & $6.67 \mathrm{c}$ & $3.14 \mathrm{c}$ & $10.61 b$ & $4.29 b$ & $18.33 \mathrm{a}$ & $7.15 \mathrm{a}$ \\
\hline 12 & $7.76 \mathrm{c}$ & $4.52 \mathrm{c}$ & $14.41 \mathrm{~b}$ & $6.83 b$ & $19.13 \mathrm{a}$ & $10.34 \mathrm{a}$ \\
\hline 15 & $12.64 \mathrm{c}$ & $5.13 \mathrm{c}$ & $18.07 \mathrm{~b}$ & $7.69 b$ & $20.55 \mathrm{a}$ & $15.36 \mathrm{a}$ \\
\hline
\end{tabular}

Note. Means followed by common letters in the row do not differ at the $5 \%$ significance level.

Figure 2 illustrates the regression models of $\log \mathrm{CFU}$ of mesophiles as a function of time within each antioxidant. The following facts can be observed:

$>$ Commercial antioxidant: the model that best fit the data was the cubic model, indicating that $0.0983 \log$ $\mathrm{CFU}$ are expected at time 0 and that their increase is not constant over time, reaching $7 \log \mathrm{CFU}$ in approximately 10.7 days;

$>$ Natural antioxidant: the model that best fit the data was the quadratic model, indicating that $0.2618 \log$ CFU are expected at time 0 and that their increase is not constant over time, reaching $7 \log$ CFU in around 6.2 days;

$>$ No antioxidant: the model that best fit the data was the cubic model, indicating that $6.0008 \log$ CFU are expected at time 0 and that their increase is not constant over time, reaching $7 \log$ CFU in 0.4 days. 


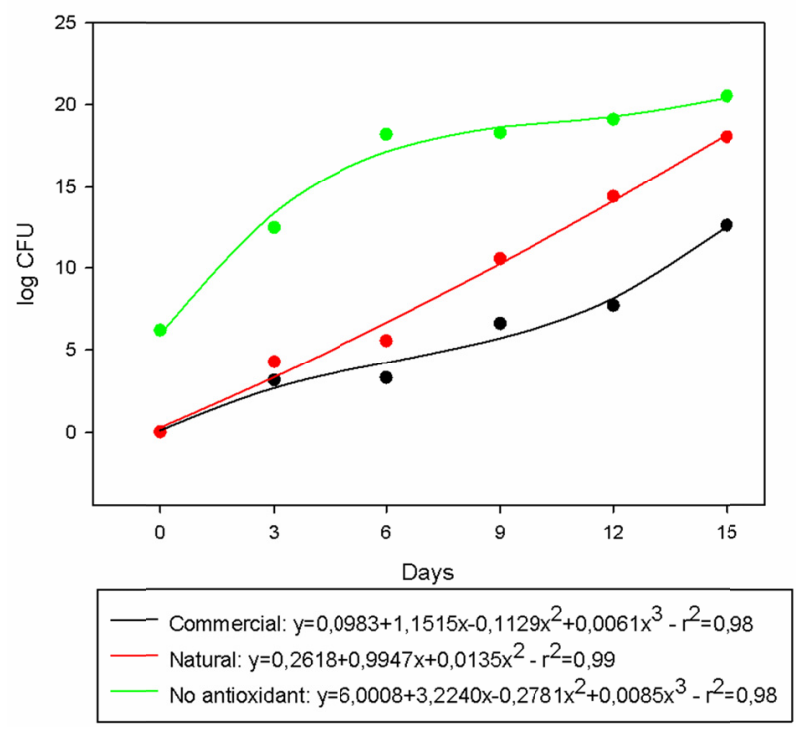

Figure 2. Regression of $\log$ CFU of mesophiles as a function of time for each treatment

According to the Brazilian legislation, there are no limits of acceptance for the count of mesophilic microorganisms, but the ICMFS (1998) establishes a maximum acceptable limit of 7 log CFU/g for the count of aerobic mesophilic bacteria, which was reached by the commercial antioxidant on the 10th day; by the natural antioxidant on the 6th day; and by the no-antioxidant treatment on the 1st day. From the 3rd day of storage, the commercial antioxidant stood out as the most efficient. This fact was expected, since it is part of the mechanism of action of compounds such as BHT to consume oxygen from the medium during its own oxidation, markedly reducing its availability for microbial growth. A similar situation was observed by Pereira et al. (2009), who compared mesophilic counts in mechanically separated chilled chicken containing natural antioxidant (yearba-mate and 'marcela' (achyrocline satureioides) extract), a commercial antioxidant (BHT), and no antioxidant addition. The authors found a shelf life of 10 days for the group treated with the commercial antioxidant; five days for the group with the natural antioxidant; and one day for the group without antioxidant treatment. However, to determine the quality, other parameters should be observed, since a low count does not mean a pathogen-free product. Products with high counts, on the other hand, may be potentially harmful to health (Morzel et al., 2003).

(4) Quantification of aerobic heterotrophic psychrotrophic microorganisms: as shown in Table 1, at time 0, all treatments led to equal results; at three days, only the no-antioxidant treatment differed; at six days, only the commercial antioxidant differed; and from nine days onwards, all treatments differed from each other. The data show that the commercial antioxidant was the most effective, followed by the natural antioxidant and lastly the no-antioxidant treatment.

The regression models (Figure 3) of the log CFU of psychrotrophs as a function of time, within each antioxidant, revealed:

$>$ Commercial antioxidant: the model that best fit the data was the cubic model, indicating that $0.1225 \log$ CFU are expected at time 0 and that their increase is not constant over time, reaching $6 \log$ CFU approximately on the 15th day;

> Natural antioxidant: the model that best fit the data was the quadratic model, indicating that $0.1628 \log$ CFU are expected at time 0 and that their increase is not constant over time; in this way, the count of psychrotrophs would reach $6 \log$ CFU in about approximately 10.6 days;

$>$ No antioxidant: the model that best fit the data was the cubic model, indicating that $0.1103 \log \mathrm{CFU}$ are expected at time 0 and that their increase is not constant over time, reaching $6 \log$ CFU in approximately 8.0 days. 


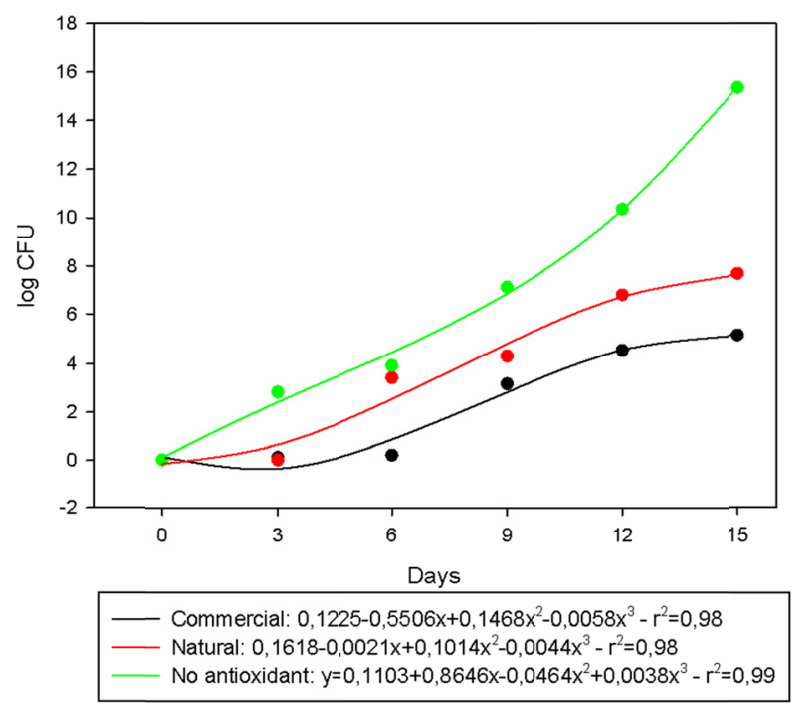

Figure 3. Regression of $\log$ CFU of psychrotrophs as a function of time for each treatment

For marine fish, the acceptable maximum threshold for the count of aerobic psychrotrophic bacteria is $6.0 \log$ CFU/g (Mol et al., 2007). However, no equivalent parameter has been proposed for freshwater fish. Therefore, considering the maximum limit of $6.0 \mathrm{log} \mathrm{CFU} / \mathrm{g}$, the shelf life of the product without antioxidant is eight days, whereas the fish treated with the natural product would be valid for 10 days. The commercial antioxidant, however, would ensure 15 days of refrigerated storage. The results observed in the present study for the no-antioxidant group differ from those reported by Pullela (1998), who found psychrotrophic bacteria counts higher than $3.0 \log \mathrm{CFU} / \mathrm{g}$ on the first day of refrigerated storage, although similar values were obtained by that group in the present experiment on the 3rd day. The groups with natural and commercial antioxidants, in turn, reached $3.0 \log \mathrm{CFU} / \mathrm{g}$ on the 6th and 9th days, respectively, demonstrating their positive effect in slowing deterioration. Between the two, the commercial version was more effective.

(5) Peroxide index (PI): lipid oxidation is the oxidative deterioration of fatty acids that can be initiated enzymatically or non-enzymatically. Its primary degradation products are hydroperoxides (Instituto Adolfo Lutz, 2008), which can be quantified by determining PI. The analysis of PI (meq/1000 g) as a function of treatments and times (Table 2) revealed that all treatments performed equally at time 0 . At three days, only the group without antioxidant differed from the others; at six days, only the treatment with commercial antioxidant was different; and at nine days, all treatments differed from each other.

Table 2. Mean values of PI (meq/1000 g) as a function of treatments and time

\begin{tabular}{llll}
\hline \multirow{2}{*}{ Time (days) } & \multicolumn{3}{c}{ Treatment (antioxidant) } \\
\cline { 2 - 4 } & Commercial & Natural & No antioxidant \\
\hline 0 & $0.00 \mathrm{a}$ & $0.00 \mathrm{a}$ & $0.00 \mathrm{a}$ \\
3 & $0.00 \mathrm{~b}$ & $0.00 \mathrm{~b}$ & $2.00 \mathrm{a}$ \\
6 & $0.00 \mathrm{~b}$ & $1.00 \mathrm{~b}$ & $4.00 \mathrm{a}$ \\
9 & $1.00 \mathrm{c}$ & $2.67 \mathrm{~b}$ & $11.33 \mathrm{a}$ \\
12 & $2.67 \mathrm{c}$ & $5.33 \mathrm{~b}$ & $19.33 \mathrm{a}$ \\
15 & $5.00 \mathrm{c}$ & $8.00 \mathrm{~b}$ & $30.00 \mathrm{a}$ \\
\hline
\end{tabular}

Note. Means followed by common letters in the row do not differ at the $5 \%$ significance level.

The Brazilian legislation does not establish standards for PI in fish, but it is known that this index measures the primary mechanisms of spoilage, mainly in meats (Motta, 2013), which makes it important to evaluate their shelf life. Queiroz et al. (1998) compared propolis extract (5\%) and BHT (10\%) in the preservation of salted bluefish (Pomatomus saltatrix) stored under refrigeration and observed a PI of $11.0 \mathrm{meq} / 1000 \mathrm{~g}$ in the samples with propolis; $0.0 \mathrm{meq} / 1000 \mathrm{~g}$ in BHT-treated samples; and $17.3 \mathrm{meq} / 1000 \mathrm{~g}$ in those without antioxidant. A similar response was observed in the current study, suggesting that the natural antioxidant may have a positive effect on 
the control of spoilage of fish. Nenadis et al. (2003), by contrast, in a comparative study of peroxide formation involving BHT, alpha-tocopherol, and caffeic acid in oil/water emulsion, showed that $100 \mathrm{mg} / \mathrm{g}$ BHT was more effective at low levels of addition of the natural product (3\%); however, when its concentration was raised to $6 \%$, alpha-tocopherol had intermediate activity and caffeic acid exceeded BHT. A similar fact would not be true for the jatobá meal tested here, since the study of concentrations showed that the saturation level is between 4.44 and 4.95 ; i.e., regardless of increases in its concentration, the antioxidant effect would not be potentiated.

(6) TBA index (TBARS 2-thiobarbituric acid): the decomposition of hydroperoxides produces a number of compounds, one of the most important and abundant of which is malonaldehyde (or malonic aldehyde (MA)) (Araújo, 2001). TBA (mg malonic aldehyde/g) is based on the reaction of this acid with the malonaldehyde present in the sample. In this study, no statistical analysis was performed for the TBA variable, because only the group without antioxidant showed results different from zero, as follows: $1 \mathrm{mg} \mathrm{MA} / \mathrm{g}$ on the 9 th day, $4 \mathrm{mg} \mathrm{MA} / \mathrm{g}$ on the 12th day, and $7.33 \mathrm{mg} \mathrm{MA} / \mathrm{g}$ on the 15 th day.

The Brazilian legislation does not indicate the maximum TBA value allowed for fish products; however, high values compromise the marketing and acceptance of the end product (Oliveira Filho, 2009). The results obtained in this study are consistent, because, unlike PI, which indicates the primary mechanisms of deterioration (Silva, 1999), TBA indicates the presence of secondary and tertiary compounds, such as malonaldehydes. Analogous results were obtained by Bertolin et al. (2011), who evaluated TBA indices in dried salted pacu (Piaractus mesopotamicus), comparing samples containing BHT (10\%) and samples containing phycocyanin (1.5\%), and observed good antioxidant activity of phycocyanin, but which was not superior to that of BHT. Queiroz et al. (1998) compared propolis extract (5\%) and BHT $(5 \%)$ in the preservation of bluefish (Pomatomus saltatrix) stored under refrigeration and found, on the 8th day of storage, $0.00 \mathrm{mg}$ malonic aldehyde/g in the samples with propolis and 6.0 malonic aldehyde/g in those without antioxidant. The data corroborate the present study, where the TBA variable showed a similar response. Chu and Hsu (1999) studied the effect of natural antioxidants (rosemary, tocopherol, and catechin) in comparison with BHT and observed, based on PI and TBA, that catechin mixed with the others significantly increased the stability of peanut oil. Regarding their findings, one can consider the possibility of associating jatobá meal with other natural antioxidants to evaluate the efficiency of their combined action in comparison with BHT.

(7) $\mathrm{pH}$ measurement: mean $\mathrm{pH}$ values were $6.29^{\mathrm{a}}$ (no antioxidant), $6.25^{\mathrm{a}}$ (natural antioxidant), and $6.15^{\mathrm{b}}$ (commercial antioxidant). These results demonstrate that the natural antioxidant and the no-antioxidant treatment can be considered equal, whereas the $\mathrm{pH}$ in the commercial-antioxidant treatment differed. RIISPOA (MAPA, 2017) established that the $\mathrm{pH}$ of fresh fish should be lower than 6.8 in the external meat, and below 6.5 in the internal meat. There are no parameters in the Brazilian law for processed fish. However, our results show that after a slight initial decline, the $\mathrm{pH}$ increased along with storage time, following the upward trend of microbiological growth. This occurs because the concentration of hydrogen oxides is almost always altered when there is hydrolytic, oxidative, or fermentative decomposition of the muscle (Sakuma, 2005). It is noteworthy that only the $\mathrm{pH}$ in the group with commercial antioxidant differed from the others, which had a higher value. This finding may be related to the fact that microbial activity was lower in the fish treated with the commercial antioxidant.

(8) Salt content: analyzed only in the samples collected on day 0 , since the parameter does not change over time. There were no differences between the salt contents of the formulations, which remained at $0.51 \pm 0.01 \%$ in all samples, showing that the type of antioxidant did not interfere with the absorption of salt by the product. Industrialized meat products like sausage and hamburger have a high concentration of salt-over 1.0\% (Costa \& Machado, 2010). Thus, the salt content observed in the pacu ribs can be considered good from the healthiness standpoint.

(9) Centesimal composition: no significant differences were observed ( $p \geq 0.05$ ) for centesimal composition between the different treatments (lipids: $2.2 \pm 0.5 \%$, protein: $24.4 \pm 1 \%$, moisture: $72.2 \pm 2 \%$, and ash: $1 \pm 0.5 \%$ ), demonstrating that not even the presence of antioxidant or lack thereof or the type of antioxidant used changed the composition of the product over the storage time.

The lipid and moisture values obtained in the present study were analogous to those observed by Souza et al. (2004), who reported respective results of $2.65 \pm 0.91 \%$ and $72.21 \pm 1.18 \%$ in tilapia filets after smoking. The protein and ash values were similar to those found by Oliveira \& Inhamuns (2005), who evaluated filets of smoked pirarucu (Arapaima gigas) $(23.30 \pm 1.21 \%$ protein and $1.12 \pm 0.4 \%$ ash).

(10) Principal Component Analysis (PCA): dimensions 1 and 2 (Figure 4) explain $85.99 \%$ and $7.47 \%$ of the variation in these traits, respectively. In all corresponding vectors, the variables show similar behavior and a size 
that approaches the circle, indicating that all have equal importance in the discrimination of the samples and a great ability to differentiate them. It can also be observed that all vectors form angles lower than $90^{\circ}$ with each other, indicating that the variables are positively correlated (lower angles signify a higher correlation between the variables). The log CFU of psychrotrophs is more closely related to PI, but the $\mathrm{pH}$ also has a high correlation with this index. The logs CFU of mesophiles and psychrotrophs are also strongly correlated.

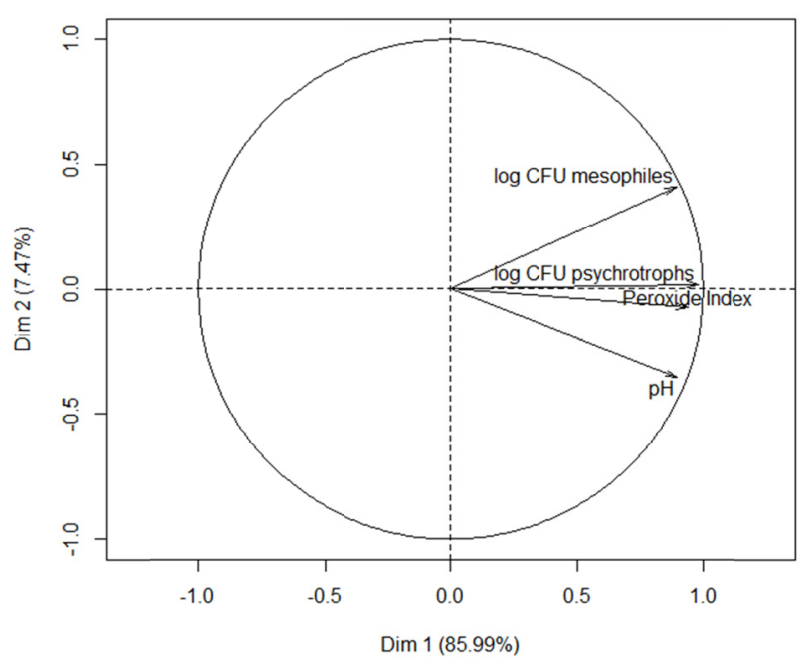

Figure 4. Principal component analysis of the variables

\section{Conclusion}

The present results demonstrate that jatobá meal has antioxidant potential and, when used at the concentration of $4.5 \%$, it had a positive effect on the shelf life of the product during storage for 15 days, but this effect was not superior to that obtained with the commercial antioxidant BHT. There were no significant sensory differences between the samples with the two antioxidants, indicating that jatobá meal can be used in this type of product. The obtained results are important for the scientific community because they prove the antioxidant potential of a product of natural origin.

\section{References}

ANVISA (Agência Nacional de Vigilânica Sanitária). (2001). Regulamento Técnico para análises microbiológicas em alimentos. Resolução RDC n.12 de 02/01/01. Brasília: Ministéio da Saúde. Retrieved from http://www.abic.com.br/publique/media/CONS_leg_resolucao12-01.pdf

Araújo, J. M. A. (2001). Química de Alimentos-Teoria e Prática. Editora Universidade Federal de Viçosa, Viçosa.

Chu, Y., \& Hsu, H. (1999). Antioxidants used in fatty foods. Food Chemistry, 66, 29. https://doi.org/10.1016/S03 08-8146(98)00082-X

Delbem, A. C. B., Garbelini, J. S., \& Lara, J. A. F. (2010). Avaliação microbiológica do Pintado (Pseudoplatystoma corruscan) obtido no rio Paraguai (Pantanal) e conservado em gelo.

Dutcosky, S. D. (2013). Análise sensorial de Alimentos. Champagmat, Curitiba.

Gonçalves, A. A. (2011). Tecnologia do pescado: Ciência, tecnologia, inovação e legislação. Atheneu, São Paulo.

Gonçalves, A. A., \& Hernández, C. P. (1998). Defumação líquida de anchova (Pomatomus saltatrix): Efeito do processamento nas propriedades químicas e microbiológicas.

Guarim Neto, G., \& Morais, R. G. (2003). Recursos medicinais de espécies do Cerrado de Mato Grosso: Um estudo Bibliográfico. Acta botânica Brasílica, 17(4), 561-584. https://doi.org/10.1590/S0102-33062003000 400009

ICMSF (International Commission on Microbiological Specifications for Foods). (1998). Pescados y derived products. Microorganisms los alimentos: Microbial ecology of them alimentary products (pp. 121-166). Zaragoza: Acribia. 
Instituto Adolfo Lutz. (2008). Métodos físico-químicos para análise de alimentos. Instituto Adolfo Lutz, São Paulo.

Larrauri, J. A., Rupérez, P., \& Saura-Calixto, F. (1997). Effect of drying temperature on the stability of polyphenols and antioxidant activity of red grape pomace peels. Journal of Agricultural and Food Chemistry, 45, 1390-1393. https://doi.org/10.1021/jf960282f

MAPA (Ministério da Agricultura, Pecuária e Abastecimento). (2017). Regulamento de inspeção industrial e sanitária de produtos de origem animal (RIISPOA). Brasília, Brazil. Retrieved from http://agricultura.gov.br/arq_editor/file/Aniamal/MercadoInterno/Requisitos/RegulamentoInspecaoIndustria 1.pdf

Maske, C., Maluf, M. L. F., Souza, B. E., Signor, A. A., Boscolo, W. R., \& Feiden, A. (2011). Composição centesimal, microbiológica e sensorial do jundiá (Rhamdia quelen) submetido ao processo de defumação. Ciências Agrárias, 32(1), 181-190.

Minozzo, M. G. (2002). Avaliação da qualidade microbiológica e bromatológica de filé de Tilápia (Oreochromis niloticus) defumado e sua vida de prateleira. Monografia Graduação em Engenharia de Pesca, Universidade Estadual do Paraná, Toledo.

Mol, S., Erkan, N., Üçok, D., \& Tosun, Y. (2007). Effect of psychrophilic bacteria to estimate fish quality. $J$. Muscle Foods, 18, 120-128. https://doi.org/10.1111/j.1745-4573.2007.00071.x

Morzel, M., \& van de Vis, H. (2003). Effects of the slaughter method on the quality of raw and smoked eels (Anguilla Anguilla L.). Aquaculture Research, 34, 1-11. https://doi.org/10.1046/j.1365-2109.2003.00754.x

Motta. E. S. (2013). Adição de ácido lático e ácido cítrico como conservante em carne mecanicamente separada. Trabalho de Conclusão de Curso (Graduação). Universidade Tecnológica Federal do Paraná, Francisco Beltrão. Retrieved from http://repositorio.roca.utfpr.edu.br/jspui/handle/1/1198

MPA (Ministério da Pesca e Aquicultura). (2013). Boletim Estatístico da Pesca e Aquicultura 2013. Retrieved from http:/www.mpa.gov.br/images/Docs/Informacoes_e_Estatisticas/Boletim\%20MPA\%202011FINAL 2.pdf

MS (Ministério da Saúde). (2016). Regulamento Técnico sobre Aditivos e Aromatizantes. Resolução de Diretoria Colegiada RDC n. 2, de 17/01/2007. Retrieved from http://www.anvisa.gov.br/legis

Nenadis, N., Zafiropoulou, I., \& Tsimidou, M. (2003). Food Chemistry. Academic Press. Turquia.

Ogawa, M., \& Maia, E. L. (1999). Manual de pesca: Ciência e Tecnologia do Pescado. Varela, São Paulo.

Oliveira, M. J. M., \& Inhamuns, A. J. (2005). Defumação à quente de diferentes cortes de Pirarucu (Arapaima gigas, Cuvier, 1829) (pp. 1553-1554). Anais Congresso Brasileiro de Engenharia de Pesca, Fortaleza.

Pullela, S. (1998). Indicative and pathogenic microbiological quality of aquacultured fish in different production system. Journal of Food Protection, 61(2), 205-210. https://doi.org/10.4315/0362-028X-61.2.205

Queiroz, M. I., Badiale-Furlong, E., \& Coelho, C. S. P. (1998). Avaliação do comportamento da oxidação de pescado salgado tratado com própolis. Ceppa, 1(2), 273-280. https://doi.org/10.20396/san.v18i2.8634682

R Core Team. (2015). R: A language and environment for statistical computing. R Foundation for Statistical Computing, Vienna, Austria. Retrieved from http://www.R-project.org

Ribeiro, A. L. M. S., Oliveira, G. M., Ferreira, V. M, Pereira, M. M. D., \& Silva, P. P. O. (2009). Avaliação microbiológica da qualidade do pescado processado, importado no estado do Rio de Janeiro. Revista Brasileira de Ciências Veterinárias, 16(3), 109-112. https://doi.org/10.4322/rbcv.2014.185

Rufino, M. S. M., Alvez, R. E., Brito, E. S., Morais, S. M., Sampaio, G. C., Pérez-Giménez, J., \& Saura-Calisto, F. D. (2007). Determinação da atividade antioxidante total em frutas pela captura do radical livre ABTS (Comunicado Técnico 128). Fortaleza; Embrapa Agroindústria Tropical.

Sakuma, A. M. (2005). Procedimentos e determinações gerais. Instituto Adolfo Lutz, Métodos Físico-Químicos Para Análises de Alimentos. ANVISA, Brasília.

Santos, L. D., Zara, R. F., Visentainer, J. V., Matsushita, M., Souza, N. E., \& Franco, M. R. L. S. (2007). Avaliação sensorial e rendimento de filés defumados de Tilápia (Oreochromis nilóticus) na presença de alecrim (Rosmarinus officinalis). Revista Ciências Agrotécnicas, 31(2), 406-412.

Silva, F. A. M., Borges, M. F. M., \& Ferreira, M. A. (1999). Métodos para avaliação do grau de oxidação lipídica e da capacidade antioxidante. Química Nova, 22, 94. https://doi.org/10.1590/S0100-40421999000100016 
Silva, N., Junqueira, V. C. A., Silveira, N. F. A., Taniwaki, M. H., Santos, R. F. S., \& Gomes, R. A. R. (2010). Manual Métodos de Análise Microbiológica de Alimentos. Varela, São Paulo.

Souza, M. L. R., Baccarin, A. E., Viegas, E. M. M., \& Kronka, S. N. (2004). Defumação de Tilápia do Nilo (Oreochromis niloticus) inteira eviscerada e filé. Revista Brasileira de Zootecnia, 33(1), 27-36.

\section{Copyrights}

Copyright for this article is retained by the author(s), with first publication rights granted to the journal.

This is an open-access article distributed under the terms and conditions of the Creative Commons Attribution license (http://creativecommons.org/licenses/by/4.0/). 